Pegem Journal of Education \& Instruction, 4(3), 2014, 35-50

Pegem Eğitim ve Öğretim Dergisi, 4(3), 2014, 35-50

www.pegegog.net

\title{
The Perceptions of the Administrators Working in Primary and Secondary Schools Related to the Organizational Dissent ${ }^{*}$
}

\author{
Bünyamin AĞALDAY ${ }^{\dagger a}$, Habib ÖZGAN ${ }^{b}$, Mustafa Cüneyt ARSLAN ${ }^{b}$ \\ ${ }^{a}$ Mardin Artuklu University, Vocational College, Mardin/Turkey \\ ${ }^{\mathrm{b}}$ Gaziantep University, Faculty of Education, Gaziantep/Turkey \\ CrossMark
}

\section{Article Info}

DOI: $10.14527 /$ pegegog.2014.015

Article history:

Received 27 December 2013

Revised 10 March 2014

Accepted 07 July 2014

Keywords:

School administrator,

Organizational dissent,

Whistleblowing.

\begin{abstract}
The research was conducted to find out the perceptions of the administrators working in primary and secondary schools related to the organizational dissent. The research contributes to the teachers in respect to their level of job satisfaction and development of positive attitude towards the school as well as the embracement of democratic units in the schools. The research is a case study from the qualitative research patterns. Working group consists of 15 school administrators (principals and deputy principals) working in primary and secondary schools in Mardın in the academic year of 2012-2013. Criterion sample method was used in determination of school administrators in working group. The research data was collected by interview method and analyzed by using descriptive and content analysis method. According to the results derived from the analysis, teachers mostly dissent in case of the assignments given to them and they prefer lateral dissent strategy. In accordance with the findings, organizing impressive communication seminars for school administrators, arranging face-to-face meetings, whose subject is apart from school affairs, between administrators and teachers periodically, and making legal regulations in respect to organizational dissent which harms educational institutions are proposed.
\end{abstract}

\section{Introduction}

In the course of time, human beings can't meet their needs by themselves and seek for collaboration in order to achieve specific goals. As a result, organizations come into being (Aydın, 2010). Organizations and people in organizations have goals, but the difference among people's goals and expectations brings along a set of disagreements and conflicts (Garner, 2006, p.3). Identification of these disagreements and conflicts contributes to flourishing of inter-organizational democracy (Kassing \& Armstrong, 2002, p.42).

The term dissent is defined as "averseness to an attitude or an opinion" or "disagreement" in the dictionary of Turkish Language Society (TDK, 1998). As a corresponding term for dissent in English, "muhalefet" is an Arabic concept which comes from the root h-I-f. Like the term "ihtilaf" coming from the same root, it means "everyone's thinking differently and dissensus" (Ardoğan 2004, p.172). In organizational sense, dissension is related to one's feeling of discordance with the organization (Kassing, 1997, p.314; Redding, 1985). Organizational dissent which is defined as the expression of the disagreements or contradictory ideas about organizational practices or policies begins with a triggering event (Graham, 1986, p.2; Kassing, 1997, p.314). This triggering event urges organization members to express and share their opposite ideas about organizational practices or policies (Kassing, 2002).

\footnotetext{
" This study is based on the paper presented at the 22nd National Education Sciences Assembly held by Eskişehir Osmangazi University, 5th-7th September, 2013.

+ Corresponding author: bagalday_47@hotmail.com
} 
Kassing \& Armstrong (2002, p.44), classify triggering events which cause organizational dissent under nine headings: employee treatment, organizational change, decision making, inefficiency, role/responsibility, resources, ethics, performance evaluation and preventing harm.

Upon encountering a negative situation, organization members have to choose a specific strategy in order to express their opposite ideas. The first strategy articulated/upward dissent emerges when organization members express their opposite ideas to the ones who have power to affect the balance in the organization (Kassing, 1997, p.326; Kassing, 1998, p.199; Kassing \& Avtgis, 1999, p.102). According to Krone (1991, p.7), organization members exhibit dissenting behaviors in five different ways in the strategy of articulated/upward dissent: direct-factual appeal, repetition, solution presentation, circumvention, threatening resignation. The second strategy lateral dissent emerges when organization members express their opposite ideas to the other organization members who do not have power to affect the balance in the organization. The third strategy displaced dissent emerges when organization members express their opposite ideas to nonmembers of the organization (Kassing, 1997, pp.326-327; Kassing, 1998, pp.190-192; Kassing, 2001, p.445). The fourth strategy whistleblowing can be defined as the proclamation of illegal and unethical behaviors in the organization by the people have information (personnel or shareholder) to the authorities in and out of the organization who have power to solve the problems in order not to harm people and institutions (Aktan, 2006, p.1).

The strategy of dissent selection is shaped in the light of individual, relational and organizational variables. Individual variables consist of job satisfaction, organizational identification, organizational burnout and focus of audit variables; relational variables consist of the variables of superior-subordinate relationship in the organization and relationship style among organization members; organizational variables consist of organizational justice and organizational democracy variables (Kassing, 2008, pp.344-345).

This study lays emphasis on the reasons and the styles of dissenting behaviors exhibited by the teachers according to the perceptions of the school principals working at primary and secondary schools. This study aims at determining the perceptions of the school principals working at primary and secondary schools about organizational dissent. In line with this aim, answers to the following questions are searched:

- To which practices of the principals do the teachers exhibit dissenting behaviors?

-What kind of dissenting behaviors do the teachers exhibit upon encountering an unpleasant situation?

Determination of the perceptions of the school principals working at primary and secondary schools about organizational dissent is essential in terms of teachers, principals and schools. Specification of the practices of principals to which the teachers exhibit dissenting behaviors and taking precautions against them may contribute to adoption of democratic values in schools; make teachers develop a positive attitude towards schools and increase their job satisfaction (Hegstrom, 1991; Redding, 1985; Stanley, 1981).

\section{Method}

\section{Research Design}

The current research is based on a qualitative approach. Qualitative research can be defined as a study design which follows a qualitative path directed at realistic and holistic disclosure of the perceptions and events in their natural settings through qualitative data collection methods such as observation, interview and document analysis (Yıldııım \& Şimşek, 2011, p.77). 


\section{Participants}

The participants of the study are 15 school principals and assistant principals working at primary and secondary schools in Mardın city center in 2012-2013 educational year. The principals and assistant principals in the study group are selected by criterion sampling method. In this sampling method, the fundamental rationale is working with all the cases which meet a set of predetermined criteria (Yıldırım \& Şimşek, 2011, p.112).

\section{Instrument}

In the study, data are collected through semi-structured interview form. Interview questions are prepared by the researchers in line with a literature review and expert opinion. Interview form consists of 5 open ended questions.

\section{Data Analysis}

When analyzing the research data, concept, one of content analysis techniques, is used. Concept is a meaning inferred from significant parts and events among obtained data (Yıldırım \& Şimşek, 2011, p.228). In the content analysis process, categorical and frequency analysis techniques are applied. Frequency analysis presents the rate of units and elements in a numeral, percental and proportional way. Categorical analysis is the division of a specific message into units and then classification of these units under categories according to some criteria (Bilgin, 2006, pp.18-19). The data obtained from the principals are coded first. Findings are analyzed and divided into meaningful parts. Then what each part represents conceptually is tried to find out. The parts which constitute a meaningful whole are entitled. In other words coding is done. Within the scope of the research, descriptive analysis is also used by means of direct quotations from the interviews with the principals. Categories and coding are done by the researchers simultaneously.

\section{Results}

According to research results, it is extrapolated that teachers' dissension results from duty and responsibility, resistance to change, restriction of personal benefit, the style of making decision and its content, inadequacy of teachers, unethical practices, prejudice, unfair practices, dissent for dissent's sake, ineffective practices, performance evaluation, providing and utilizing resources respectively. According to research findings, dissenting behaviours exhibited by the teachers are in the themes of lateral dissent, upward dissent, whistleblowing and displaced dissent respectively.

\section{Discussion, Conclusion \& Implementation}

Principals express that some of the teachers consider some duties as a kind of "busywork" and they dissent principals by putting forward various reasons. Similarly, Köksal (2008) concludes that teachers resist performing some duties or consider some duties as a "busywork" in his research.

In light of the research findings, it is concluded that one of the factors which causes teachers to dissent is change. With respect to general consent in the field, organization members resist organizational innovation and change (Korkut, 2009; Zayim, 2005). In a research on resolution of conflicts between superior and subordinates in the organizations, Baykal \& Kovancl (2008) state that one of the reasons of conflict in the organizations is difference of interests between superior and subordinates. On the basis of this finding, it can be asserted that besides causing conflict, difference of interests triggers organizational dissent. 
In addition, teachers may exhibit dissenting behaviors with the influence of organizational decisions of the principals and the way they do. The principals' decisions about organizational practices are related to their leadership style. In this research, it is concluded that teachers may exhibit dissenting behaviors against authoritative management mentality. The principal with this mentality centralize the authority on him. Whereas organization members opt for a democratic management mentality in which their needs and preferences are taken into consideration and in which they participate in decisionmaking. In this regard, it must be given opportunity for teachers to question the decisions taken; the decisions about the teachers should be clarified with the reasons when needed and teachers must be informed on time.

One of the findings of this research is that teachers regard unethical practices as a reason of dissension. Teachers dissent as they think that some of the practices of the principals are unfair. One of them is principals' nepotistic behaviors (Aydın, 2002, p.60; Bozkurt \& Ergun, 1998, p.117). Özdemir's (2010) and Ağalday (2013)'s studies support this finding. When behaviors of principals are perceived as ethically right by the organization members, they become meaningful (Arslantaş \& Dursun, 2008, p.115). Principals' unethical statements and behaviors decrease the productivity as they damage interorganizational communication climate.

When dissenting behaviors exhibited by the teachers are analyzed, it is understood that teachers prefer lateral dissent strategy. According to principals' perceptions, teachers may be offended. This finding supports Hirschman's "exit, voice, and loyalty" theory. In his study, Hirschman (1970) asserts that some part of unhappy organizational members may exhibit exit behavior. Additionally this finding supports Gorden \& Infante's (1987) "independent mindedness theory". This theory asserts that organization members will be more committed to their job if they express all the ideas they belong including dissent ones in the organization freely. Based upon this proposal, it can be asserted that organizational members who cannot express dissent ideas explicitly will be offended and their commitment will decline. Consequently, it can be anticipated that as organization members' job commitment declines, they tend to exit the organization. The more organization members feel themselves as parts of the organization and vice versa and the more they commit to the membership of the organization, the more they want to remain there. They sincerely make more endeavors to contribute collaborative work in the organization (Aydın, 2007, p.23).

It is found that teachers may also slowdown the business within the scope of lateral dissent. Farrell \& Rusbult (1992) identify these as "neglect" behaviors and exemplifies these kinds of behaviors as disappearance of organization members' eagerness to work, their making habit of coming to job late and shirk their duties. In some cases, organization members do not openly express their dissent opinions against some practices or policies of the organization with the worry of the restriction of their personal benefits. This makes organization members keep silent or tell their dissent opinions to the other organization members (Kassing \& Avtgis, 1999, p.103). The organization members who are not in any managerial position in the organization and in contact with external power groups generally prefer lateral dissent strategy (Kassing, 1998, p.193; Kassing \& Armstrong, 2009, p.226; Kassing \& Avtgis, 2009, p.120). On the contrary, young organization members who have less work experience prefer displaced dissent strategy (Kassing \& DiCioccio, 2009, p.114).

Teachers prefer upward dissent strategy secondarily after lateral dissent strategy. It is known that this strategy is preferable when there is a good relationship between principals and teachers and it contributes to the development of democratic management mentality in schools (Kassing, 1998). Therefore, it is suggested that principals' provision of the settings in which teachers prefer upward dissent strategy may contribute to effective management of dissension. Additionally, it is found that teachers report the unpleasant situations they encounter at school to authorized organizations and institutions. However, many teachers may not report them to external organizations with the thought of getting harmed. Hence, it is recommended that necessary precautions must be taken and legal arrangements must be done immediately for teachers to communicate their dissent opinions about school to external powerful respondents. 
İlkokul ve Ortaokullarda Görevli Yöneticilerin Örgütsel Muhalefete İlişkin Algıları

\author{
Bünyamin AĞALDAY ${ }^{\dagger a}$, Habib ÖZGAN ${ }^{b}$, Mustafa Cüneyt ARSLAN ${ }^{b}$ \\ ${ }^{a}$ Mardin Artuklu Üniversitesi, Meslek Yüksekokulu, Mardin/Türkiye \\ ${ }^{\mathrm{b}}$ Gaziantep Üniversitesi, Eğitim Fakültesi, Gaziantep/Türkiye
}

\section{Makale Bilgisi}

DOI: $10.14527 /$ pegegog.2014.015

Makale Geçmişi:

Geliş 27 Aralık 2013

Düzeltme 10 Mart 2014

Kabul $\quad 07$ Temmuz 2014

Anahtar Kelimeler:

Okul yöneticisi,

Örgütsel muhalefet,

Haber uçurma.

\section{Öz}

Bu araştırmanın amacı, ilkokul ve ortaokullarda görevli yöneticilerin örgütsel
muhalefete ilişkin algılarının belirlenmesidir. Bu araştırma, okul içi demokratik öğelerin
benimsenmesine katkı sağlamakla birlikte, öğretmenlerin okula karşı olumlu tutum
geliştirmelerine ve iş doyum düzeylerinin artmasına katkı sağlaması açısından
önemlidir. Araştırma, nitel desende oluşturulmuştur. Araştırmada, nitel araştırma
desenlerinden araştırmanın doğasına uygun olan durum çalışması kullanılmıştır.
Çalışma grubu, 2012-2013 eğitim-öğretim yılında Mardin il merkezinin ilkokul ve
ortaokullarında görevli 15 müdür ve müdür yardımcısından oluşmaktadır. Çalışma
grubundaki yöneticilerin belirlenmesinde ölçüt örnekleme yöntemi kullanılmıştır.
Araştırma verileri görüşme yöntemi ile elde edilmiştir. Veriler, betimsel ve içerik analizi
yöntemleri kullanılarak analiz edilmiş ve yorumlanmıştır. Verilerin analizi sonucunda,
öğretmenlerin en çok kendilerine verilen görevler karşısında muhalif davranışlar
sergiledikleri ve bununla birlikte yatay muhalefet stratejisini tercih ettikleri sonucuna
ulaşılmıştır. Bu bulgular doğrultusunda, okul yöneticilerine etkili iletişim seminerleri
verilmesi, okul yöneticilerinin öğretmenlerle okul işleri dışında belirli zaman
aralıklarıyla birebir görüşme saatinin ayarlanması ve eğitim kurumlarına zarar verme
noktasında örgütsel muhalefete ilişkin yasal düzenlemeler yapılması konularında
öneriler geliştirilmiştir.

Giriş

İnsanlar zamanla ihtiyaçlarını tek başlarına karşılayamamışlar ve belirli amaçları gerçekleştirmek için işbirliği yapma ihtiyacı duymuşlardır. Bunun neticesinde de örgütler meydana gelmiştir (Aydın, 2010). Örgütlerin ve örgüt içerisinde bulunan bireylerin amaçları vardır; ancak, örgütlerde insanların hedefleri ve beklentilerinin farklı olması, beraberinde birtakım anlaşmazlıkları ve ihtilafları getirir (Garner, 2006, s.3). Bu anlaşmazlıkların ve ihtilafların belirlenmesi, örgüt içi demokrasinin gelişimine katkı sağlamaktadır (Kassing ve Armstrong, 2002, s.42).

Türk Dil Kurumu (TDK,1998) sözlüğünde muhalefet kavramı, "bir tutuma, bir görüşe, bir davranışa karşı olma durumu" ya da "aykırılık" olarak tanımlanmaktadır. Muhalefet, h-l-f kökünden gelen Arapça bir kavramdır. Aynı kökten gelen ihtilaf kavramı gibi, 'herkesin ayrı bir yol tutması ve görüş ayrılığı' anlamına gelmektedir (Ardoğan 2004, s.172). Örgütsel bağlamda düşünüldüğünde muhalefet, kişinin örgütte aykırı hissetmesi ile ilgili bir kavramdır (Kassing, 1997, s.314, Redding, 1985). Örgütsel muhalefet, örgüt üyelerinin, örgüt içindeki birtakım uyuşmazlıkları ve aykırı görüşleri dile getirmeleri olarak tanımlanmaktadır (Kassing, 1997, s.326). Tanımdan da anlaşıldığı üzere, örgütsel muhalefeti sadece görüş ayrılığına düşmek biçiminde tanımlamak yeterli değildir. Örgütsel muhalefet sürecinde örgüt üyeleri, bir yandan örgütsel yönetimle fikir ayrılığına düşerken, diğer yandan bu fikir ayrılığını ifade

\footnotetext{
*Bu çalışma, Eskişehir Osmangazi Üniversitesi Eğitim Fakültesi (5-7 Eylül, 2013) tarafından düzenlenen 22.Ulusal Eğitim Bilimleri Kurultayı'nda sözlü bildiri olarak sunulmuştur

+Corresponding author: bagalday_47@hotmail.com
} 
etmektedirler. Esas itibariyle, muhalefet çalışanların yalnızca kendi karakterlerinin farkında olmalarını değil, daha çok, çalışma ortamlarındaki sosyal ve örgütsel konumlarını anlamalarını da gerektiren çok kişiselleştirilmiş bir davranıştır (Kassing, 2008, s.343).

Örgüt üyeleri, muhalif görüşlerini dile getirmeden önce örgüt içerisinde bir sorun olduğunu algılamaktadırlar. Bu algılamayla birlikte, bu sorunun ciddiyetinin farkında olmaları ve muhalif görüşlerini sergilemeleri durumunda kendilerine yönelik verilecek tepkileri ölçmektedirler (Graham, 1986, s.3). Örgütsel uygulamalar ya da politikalarla ilgili anlaşmazlıkların ya da zıt fikirlerin ifadesi olarak tanımlanan örgütsel muhalefet, tetikleyici bir olayla başlar (Graham, 1986, s.2; Kassing, 1997, s.314). Bu tetikleyici olay, örgüt üyelerini, örgütsel uygulamalar ve politikalar hakkındaki muhalif fikirlerini dile getirme ve paylaşma zorunluluğunu hissetmelerine sevk eder (Kassing, 2002).

Kassing ve Armstrong (2002, s.44), örgütsel muhalefete yol açan tetikleyici olayları dokuz başlık altında toplamıştır. Bunlardan ilki, yöneticilerin örgüt üyelerine yönelik davranışlarının adaletsiz ve örgüt üyelerinin haklarını ihlal edici yönde olması; ikincisi, örgütsel değişme; üçüncüsü, örgütsel kararlar ve bu kararların alınma biçimi; dördüncüsü, örgüt içindeki etkisiz yönetici uygulamaları; beşincisi, yöneticilerin kendilerinin ya da diğer örgüt üyelerinin görev ve sorumluluklarını yerine getirmemeleri; altıncısı, örgütsel kaynakların temin edilmesi ve kullanılmasına ilişkin adaletsiz uygulamalar; yedincisi, yöneticilerin örgüt içi etik dışı uygulamaları; sekizincisi, yöneticilerin kendilerinin ya da diğer örgüt üyelerinin performanslarının değerlendirilmesi; dokuzuncusu ise, yöneticiler tarafından sergilenen örgütsel kimi uygulamaların örgüt üyesinin kendisine, örgütteki arkadaşlarına ya da müşterilerine zarar vermesidir.

Örgüt üyeleri, kötü bir durumla karşılaştıklarında, muhalif görüşlerini ifade etmek için belirli bir strateji seçmek durumundadırlar. Bu stratejilerden ilki, "açıkça belirtilmiş ya da dikey muhalefet (articulated/upward dissent)" stratejisidir. Açıkça belirtilmiş muhalefet, örgüt üyelerinin muhalif görüşlerini, örgütteki dengeleri etkileyebilecek kişilere ifade ettiklerinde oluşmaktadır. Açıkça belirtilmiş muhalefet, muhalif görüşlerin yöneticilere yönelik direk ve açık bir şekilde ifadesini kapsar. Krone (1991, s.7)'a göre örgüt üyeleri, açıkça belirtilmiş muhalefet stratejisinde, muhalif davranışlarını beş farkı türde sergilemektedir: 1.Doğrudan Olgusal İtiraz (direct-factual appeal); örgüt üyelerinin somut kanıtlara ve çalışma deneyimine dayanarak, çalışma arkadaşlarının muhalif iddiasını destekleyerek, 2.Tekrarlama (repetition); örgüt üyelerinin muhalif davranışlarına sözlü ve davranışsal olarak ilgi çekmeyi sürdürerek örgütsel yönetimi etkilemeye çalışmak, 3.çözüm Önerisi Sunma (solution presentation); muhalefeti tetikleyen olayın kanıtlanması yerine bunun çözümü için önerilerde bulunarak, 4.Önleme (circumvention); örgüt üyesinin, muhalefetini, emir komuta zinciri içinde, örgüt üyesininin üstüne bildirerek 5. Istifa Tehdidinde Bulunmak (threatening resignation); istifa tehdidini, yönetimden istenen değişikliklerin yapılması için, baskı aracı olarak kullanarak.

Örgüt üyelerinin ikinci muhalefet stratejisi ise "yatay muhalefet (lateral dissent)" stratejisidir. Yatay muhalefet, örgüt üyelerinin muhalif görüşlerini, örgütteki dengeler üzerinde etkisi olmayan diğer örgüt üyelerine ifade ettiklerinde oluşmaktadır. Yatay muhalefet davranışının sergilenmesi, temel olarak örgüt üyelerinin, örgüt içinde kendilerinin düşman ya da rakip olarak algılandıklarını düşündükleri durumda ortaya çıkmaktadır (Kassing, 1998, s.191). Bazı durumlarda, örgüt üyeleri, örgütteki kimi uygulama ya da politikaya karşı, çıkarlarının zedeleneceği endişesiyle, muhalif görüşlerini açıkça ifade etmezler. Bu durum, örgüt üyelerinin ya sessiz kalmasına ya da örgüt üyelerinin muhalif görüşlerini örgütteki diğer arkadaşlarına anlatmasına neden olmaktadır (Kassing ve Avtgis, 1999, s.103).

Örgüt üyelerinin seçtikleri üçüncü muhalefet stratejisi ise "yer değiştirmiş muhalefet (displaced dissent)" stratejisidir. Bu muhalefet stratejisi, örgüt üyelerinin muhalif görüşlerini örgüt dışındakilerine aktarmayı tercih ettiklerinde oluşur (Kassing, 1997, ss.326-327; Kassing, 1998, ss.190-192; Kassing, 2001, s.445). Örgüt dışındakiler; örgüt üyelerinin örgüt dışındaki arkadaşları, eşleri, partnerleri ve aile üyelerinden oluşmaktadır. Örgüt üyeleri, örgütteki birtakım uygulamalar ya da politikalarla ilgili muhalif görüşlerine karşı misilleme tehdidi olduğunu hissederse, yer değiştirmiş muhalefet stratejisini kullanmaktadır. Örgüt üyeleri, muhalif görüşlerini örgüt dışındakilere dile getirerek, kendilerine yönelik 
sergilenecek misilleme davranışlarını azaltma amacı taşımaktadırlar. Örgüt üyeleri, örgütten ayrılmayı fiziksel olarak düşünmemekle birlikte, muhalif görüşlerini örgütsel sınırların dışında kalanlarla paylaşarak psikolojik olarak örgütten ayrılmayı deneyebilirler (Kassing, 1997, s.326). Örgüt içinde herhangi bir yönetimsel pozisyonda bulunmayıp, örgüt dışındaki güç odaklarıyla iyi ilişkiler içinde olan örgüt üyeleri, daha çok yatay muhalefet stratejisini tercih ederler (Kassing, 1998, s.193; Kassing ve Armstrong, 2009, s.226; Kassing ve Avtgis, 2009, s.120). Bunun yanında, iş deneyimi daha az olan genç yaştaki örgüt üyeleri, yer değiştirmiş muhalefet stratejisini tercih ederler (Kassing ve DiCioccio, 2009, s.114).

Örgüt üyelerinin seçtikleri dördüncü muhalefet stratejisi ise "haber uçurma (whistleblowing)" stratejisidir. Haber uçurma, bir organizasyon içerisinde yasadışı ve etik değerlere uygun olmayan davranış ve eylemlerin organizasyon içi ve/veya organizasyon dışı başka kişilere veya kurumlara zarar vermemesi için enformasyon sahibi kişiler (çalışanlar veya paydaşlar) tarafından sorunları çözme güç ve yetkisine sahip iç ve dış otoritelere bildirilmesi olarak tanımlanabilir (Aktan, 2006, s.1).

Muhalefet seçimi stratejisi bireysel, ilişkisel ve örgütsel değişkenlerin ışığında şekillenir. Bireysel değişkenler, bireysel iletişim davranışları, örgütte şekillenen davranışları ve dış çevreden örgüte aktarılmış davranışları ya da değerleri ile ilişkili iken, ilişkisel değişkenler, insanların örgütlerde sergilediği ilişkilerin tipi ve kalitesi ile ilişkilidir. Örgütsel değişkenler ise, örgüt üyelerinin örgütü nasıl algıladıkları ile ilişkilidir (Kassing, 1997, ss.322-324). Bireysel değişkenler iş doyumu, örgütsel özdeşleşme, örgütsel tükenmişlik ve denetim odağı değişkenlerinden; ilişkisel değişkenler, örgütteki ast-üst ilişki biçimi ve örgüt üyeleri arasındaki ilişki biçimleri değişkenlerinden; örgütsel değişkenler ise örgütsel adalet ve örgütsel demokrasi değişkenlerinden oluşmaktadır (Kassing, 2008, ss.344-345).

Bu araştırmada, ilkokul ve ortaokullarda görevli yöneticilerin görüşlerine göre öğretmenlerin muhalif davranışlar sergilemelerinin nedenleri ve muhalif davranış sergileme biçimleri üzerinde durulacaktır. Bu araştırmanın amacı, ilkokul ve ortaokullarda görevli yöneticilerin örgütsel muhalefete ilişkin görüşlerinin belirlenmesidir. Amaç doğrultusunda aşağıdaki sorulara cevap aranmıştır:

- Öğretmenler yöneticilerin hangi uygulamalarına karşı muhalif davranışlar sergilemektedir?

- Öğretmenler, hoşlanmadıkları bir durumla karşılaştıklarında ne tür muhalif davranışlar sergilemektedirler?

Illkokul ve ortaokullarda görevli yöneticilerin örgütsel muhalefete ilişkin görüşlerinin belirlenmesi, öğretmen, yönetici ve okul açısından önem taşımaktadır. Öğretmenlerin muhalif davranışlar sergilemesine neden olan yönetici davranışlarının belirlenmesi ve buna yönelik tedbirlerin alınması, okul içi demokratik öğelerin benimsenmesine katkı sağlamakla birlikte, öğretmenlerin okula karşı olumlu tutum geliştirmelerine ve iş doyum düzeylerinin artmasına katkı sağlayabilir (Hegstrom, 1991; Redding, 1985; Stanley, 1981). Bunun yanında, öğretmenlerin örgütsel muhalif davranış biçimlerinin belirlenmesi, okul içi iletişim yapısının anlaşılmasına katkı sağlayabilir. Örgüt içi ilişki yapısı, örgüt üyelerinin muhalif davranış biçimlerini etkilemektedir (Kassing, 1998). Bu araştırmayla, muhalif öğretmenlerin sergiledikleri muhalif davranış biçimlerinden yola çıkarak, örgüt içi iletişim yapısıyla ilgili düzenleme çalışmaları yapılmasına olanak sağlanabilir. Bu kapsamda gerçekleştirilen araştırmanın sonucunda, sonraki araştırmalara yön verebilecek ipuçları elde edilebilir.

\section{Yöntem}

\section{Araştırma Modeli}

Araştırma, nitel desende oluşturulmuştur. Araştırmada amaç, öğretmenlerin yöneticilerin hangi uygulamalarına karşı muhalif davranışlar sergilediğini ve bu davranışlarla karşılaştıklarında öğretmenlerin ne tür muhalif davranışlar sergilediğini belirlemek olduğu için, nitel araştırma desenlerinden araştırmanın doğasına uygun olan durum çalışması kullanılmışır. Bu araştırma deseninde, bir duruma ilişkin etkenler bütüncül bir yaklaşımla araştırılır ve ilgili durumu nasıl etkiledikleri ve ilgili durumdan nasıl etkilendikleri üzerinde odaklanılır (Yıldııım ve Şimşek, 2011, s.77). 


\section{Katılımcılar}

Bu araştırma, 2012-2013 eğitim-öğretim yılında Mardin il merkezinin ilkokul ve ortaokullarında görevli 15 müdür ve müdür yardımcısı üzerinde yapılmıştır. Çalışma grubundaki yöneticilerin belirlenmesinde ölçüt örnekleme yöntemi kullanılmıştır. Bu örnekleme yöntemindeki temel anlayış, önceden belirlenmiş bir dizi ölçütü karşılayan bütün durumların çalışılmasıdır (Yıldırım ve Şimşek, 2011, s.112). Herhangi bir sendikaya üyeliği bulunan yöneticiler, random yoluyla araştırma kapsamına alınmıştır. Araştırmaya sadece sendika üyeliği bulunan yöneticilerin dahil edilmiş olması, sendika geleneğinin özünde, muhalefet geleneğinin olması ve sendika üyeliği bulunan kişilerin daha fazla muhalif davranış sergileme eğilimi içerisinde olabileceği ya da muhalif davranışlara maruz kalabileceği düşüncesidir. Araştırmaya katılan 15 yöneticiden 13'ü erkek 2'si kadındır. Görüşme yapılan yöneticilerden 9'u okul müdürü, 6'sı müdür yardımcısıdır. Yöneticilerin yaşları 28-45 arasındadır. Bulundukları okulda çalışma süreleri ise bir yıl ile dört yıl arasında değişmektedir. Araştırma yapılan okullardan 3'ü ilkokul, 2'si ise ortaokuldur.

\section{Veri Toplama Araçları}

Araştırmada veriler yarı-yapılandırımış bir görüşme formu ile toplanmıştır. Araştırmada kullanılan görüşme soruları araştırmacılar tarafından ilgili alanyazının taranması ve gerekli uzman görüşlerinin alınmasıyla hazırlanmıştır. Görüşme formu 5 açık uçlu sorudan oluşmaktadır:

- Okulunuzda görevli öğretmenler hangi tür uygulamalarınıza karşı muhalif davranışlar sergilemektedir, örneklerle açıklar mısınız?

- Muhalif öğretmenler ne tür davranışlar sergilemektedir, örneklerle açıklar mısınız?

- Öğretmenler onaylamadıkları bir tutum sergilediğinizde bunu, basın kuruluşları, sivil toplum kuruluşları, meslek kuruluşları ya da siyasi partilere rapor etmekte midir, örneklerle açıklar mısınız?

- Öğretmenler onaylamadıkları bir tutum sergilediğinizde bunu, doğrudan sizinle konuşmakta mıdır, örneklerle açıklar mısınız?

- Öğretmenler onaylamadıkları bir tutum sergilediğiniz durumlarda, küsme ve işi yavaşlatma gibi davranışlar sergiler mi, muhalif öğretmenler diğer öğretmenlerden kendisine destek arar mı, örneklerle açıklar mısınız?

\section{Verilerin Toplanması}

Görüşmeler okul yöneticilerinin kendi odalarında önceden randevu alınarak birebir gerçekleştirilmiş olup, ortalama olarak 45 dakika sürmüştür. Görüşmede ses kaydı yapılmış, bu kayıtlar daha sonra yazılı hale getirilerek kontrol etmeleri amacıyla görüşülen yöneticilere tekrar gönderilmiş ve onayları alınmıştır. Ayrıntılı bilgi toplanmaya çalışılmıştır. Verilerin çözümlenmesi sonucu; bulgular kendi içinde tutarlı, anlamlı ve daha önceden oluşturulan kavramsal çerçeve ve kuramlarla uyumlu şekilde çıkmıştır. Kirk ve Miller (1986)'e göre nitel araştırmada "geçerlik", araştırmacının araştırdığı olguyu olduğu biçimiyle ve olabildiğince yansız gözlemesi ile ilgiliyken "güvenirlik" ise bilimsel bulguların tekrarlanabilirliği ile ilgilidir (Akt. Yıldırım ve Şimşek, 2011, ss.255-260). Bu doğrultuda araştırmanın geçerliği ve güvenirliğini artırmak için birtakım önlemler alınmıştır:

Araştırmanın iç geçerliğini artırmak için görüşme formu geliştirilirken ilgili literatür incelemesi sonucunda konu ile ilgili kavramsal bir çerçeve oluşturulmuştur. Görüşme sonrası yöneticilerin söyledikleri yazılı hale dönüştürülmüş ve bu metin, görüşme yapılmış yöneticilere tekrar gönderilerek yöneticilerden kontrol etmeleri istenmiş, böylece katılımcı teyidi alınmıştır. 
Araştırmanın dış geçerliğini artırmak için araştırma süreci ve bu süreçte yapılanlar ayrıntılı bir şekilde açıklanmıştır. Bu bağlamda, araştırmanın modeli, çalışma grubu, veri toplama aracı, veri toplama süreci, verilerin çözümlenmesi ve yorumlanması ayrıntılı bir biçimde tanımlanmıştır.

Araştırmanın iç güvenirliğini arttırmak için bulguların tamamı yorum yapılmadan doğrudan verilmiştir.

Araştırmanın dış güvenirliğini artırmak için görüşme formu geliştirilirken ilgili literatür incelemesi sonucunda konu ile ilgili kavramsal bir çerçeve oluşturulmuştur. Bu araştırmada ilgili çalışma grubunun kimlerden oluşacağının açıkça ifade edilmiş olması da, araştırmanın dış güvenirliğini artırıcı bir etkiye sahiptir. Ayrıca, süreçte yapılanlar ayrıntılı bir biçimde tanımlanmıştır.

\section{Verilerin Analizi}

Araştırma kapsamında elde edilen verilerin çözümlenmesinde içerik analizi türlerinden kavram kullanılmıştır. Kavram, veriler arasında yer alan anlamlı bölümlere ve olaylara verilen anlamdır (Yıldırım ve Şimşek, 2011, s.228). İçerik analizinde kategorisel ve frekans analizi teknikleri kullanılmıştır. Frekans analizi, birim ve öğeleri sayısal, yüzdesel ve oransal bir tarzda görülme sıklığını ortaya koymaktır. Kategorisel analiz ise, belli bir mesajın önce birimlere bölünmesi ve ardından bu birimlerin, belirli kriterlere göre kategoriler halinde gruplandırımasıdır (Bilgin, 2006, ss.18-19). Yöneticilerden alınan cevapların analizinde önce kodlama yapılmıştır. Bulgular incelenerek, anlamlı bölümlere ayrılmış ve her bölümün kavramsal olarak ne ifade ettiği bulunmaya çalışılmıştır. Daha sonra kendi içinde anlamlı bir bütün oluşturan bölümler isimlendirilmiş yani kodlama yapılmıştır. Araştırma kapsamında ayrıca, yöneticilerle yapılacak görüşme formlarında doğrudan alıntılar yapılarak betimsel analiz de kullanılmıştır. Kategori ve kodlamalar araştırmacılar tarafından birlikte oluşturulmuştur.

\section{Bulgular}

$\mathrm{Bu}$ bölümde, yöneticilerin görüşleri ana ve alt temalar eşliğinde sırasıyla sunulmaktadır. Öğretmenlerin, okul yöneticilerinin görüşlerine göre muhalefet etme nedenlerine ilişkin alt temalar ve frekansları Tablo 1'de verilmiştir.

Tablo 1.

Muhalefetin Nedenlerine Iliş̧kin Alt Temalar ve Frekansları.

\begin{tabular}{llr}
\hline Ana tema & Alt temalar & $\mathbf{f}$ \\
\hline Muhalefet etme nedenleri & Görev ve sorumluluk & 12 \\
& Değişime direnç & 10 \\
& Kişisel çıkarın zedelenmesi & 9 \\
& Kararların alınma biçimi ve içeriği & 8 \\
& Öğretmenlerin yetersizliği & 7 \\
Etik dışı uygulamalar & 6 \\
Önyargı & 4 \\
Adaletsiz uygulamalar & 3 \\
Muhalefet için muhalefet & 3 \\
Etkisiz uygulamalar & 2 \\
Performans değerlendirme & 1 \\
Kaynakların temin edilmesi ve kullanılması & 1 \\
Toplam & 62 \\
\hline
\end{tabular}

Tablo 1 incelendiğinde, öğretmenlerin muhalefet etme nedenlerinin sırasıyla; görev ve sorumluluk, değişime direnç, kişisel çıkarın zedelenmesi, kararların alınma biçimi ve içeriği, öğretmenlerin yetersizliği, 
etik dışı uygulamalar, önyargı, adaletsiz uygulamalar, muhalefet için muhalefet, etkisiz uygulamalar, performans değerlendirme ve kaynakların temin edilmesi ve kullanılması olduğu görülmektedir.

Okul yöneticilerine göre, öğretmenler en fazla, kendilerine verilen görev ve sorumluluklar ile ilgili muhalif davranışlar sergilemektedir. Görev ve sorumluluklar ile ilgili yönetici görüşleri; “...Pek çok defter, dosya ve resmi evrak elektronik ortamda tutulabilir; ancak bu evrakların kağıt üzerinde de tutulması zorunludur. Bu durumu mantıklı bulmayan öğretmenler verilen göreve rağmen kağıt üzerinde belge düzenlemeyi reddetmektedir (K5).", “...Öğretmenler re'sen görevlendirildiği kurslara ya da seminerlere gitmeyi bazen reddetmektedirler. Bu tip durumlarda, 'Niye ben, zaten programda geri kalmışım, başkaları da var' tarzında tepkisini dile getirdiği de oluyor (K1)." şeklindedir.

Değişime direnç gösterme ile ilgili bir yönetici görüşü; “...Okulumuzda, ilk ve ortaokul öğrencileri bir arada öğrenim gördüğü için teneffüs ve ders saatlerinde düzenleme yaptık, öğretmenlerimiz 'Bu mümkün değil, bu uygulamayı yürütmek çok zor, eski köye yeni adet mi getireceksiniz' şeklinde tepkiler verdi. Bu tepkiler hala da devam etmektedir (K12)." şeklindedir.

Kişisel çıkarları zedelenme ile ilgili olarak yönetici görüşleri; “...Öğretmen, okuldaki ders programının, okul dışı gündelik yaşantısını olumsuz etkilemeyecek, bazı günleri boş olacak şekilde yapılması beklemektedir, aksi halde muhalif davranışlar sergileme eğilimi içerisinde olabilmekte ve bizimle karşı karşıya gelebilmektedir (K15).", "...4+4+4 ile birlikte 5.sınıflarda fazladan seçmeli dersler getirildi. Bu dersler sabah erken saate konulduğu için öğretmenler kendi aralarındaki konuşmalarda, sabah erken uyanamadıkları için bu duruma itiraz ettiklerine şahit olduk bize ise; 'O saatte ders mi olur, öğrenci sınıfta uyuyacak' gibi bahaneler sundular (K2)." şeklindedir. Öğretmenler, yöneticilerin aldıkları kararların içeriğine ve alınma biçimine karşı muhalif davranışlar sergilemektedir. Bu konuyla ilgili olarak bir yönetici görüşü; "...Etkinlik kulübünü belirleme toplantısında, bir öğretmenimiz hiçbir kulüpte görev almak istemedi. Nedenini sorduğumuzda ise yaptığımı işin usulsüz olduğunu ve seçimle yapılması gerektiğini söyledi. Öğretmenimize seçimle yaptığımızı ancak kimsenin gönüllü olarak istemediğini söyleyince de 'Olsun, sizin yine de bize danışmanız, seçim yapmanız gerekiyordu' diyor (K8)." şeklindedir.

Öğretmen yetersizliği ile ilgili olarak yönetici görüşleri; “...Bazı öğretmenlerin bilgisayarı kullanamadıkları için e-okul sistemine, not ve bilgi girişi yapamadığını görüyoruz. Niçin yapmadıklarını sorduğumuzda; 'ben yapamam' türünden tepkilerle karşılaşıyoruz (K7).", "4. sınıf ve üstü öğretmenlerin resim, müzik, beden eğitimi, İngilizce gibi özel bilgi ya da yetenek gerektiren derslere girmek zorunda kaldıklarında, 'ben bu programı verecek düzeyde değilim' diyerek mevcut müfredatı takip etmek istemediklerine şahit oldum (K14)." şeklindedir.

Etik dışı uygulamalarla ile ilgili olarak bir yönetici görüşü; “...Iş̧ini iyi yapan öğretmen beni eleştirsin, bana karşı çıksın ikna olurum. Diğer öğretmenlere göre söz konusu öğretmenimize daha esnek davranııım. Bazı öğretmenleri kayırdığımı söyleyen öğretmenlere de 'siz de işinizi iyi yapın sizi de kayırayım' diyorum (K3)." şeklindedir.

Öğretmenler, bazı konularda önyargııı oldukları için muhalif davranışlar sergilemektedir. Bu konuyla ilgili olarak yönetici görüşleri; “...Öğrencilerimizin akademik başarılarını artırmak için yaptığımız uygulamalarda öğretmenlerin, 'Müdür beyin öğrencileri düşündüğü yok, kendisini ön plana çıkarmak istiyor' dediği kulağımıza geliyor. Bu yüzden yeni uygulamalarının gerekliliğine inanmıyorlar (K10).", "Farklı sendikalarda olduğumuz bazı öğretmenler sadece bu sebepten aldığım kararlara muhalefet edebilmektedir (K12)." şeklindedir.

Görüşülen yöneticiler genel olarak, öğretmenlerin kendilerine verilen görevlerle ilgili aykırı görüş dile getirdiklerini belirtmişlerdir. Asıl sorumlulukları olan öğretim faaliyetleri dışında herhangi bir etkinliğe katılmak istemediklerini vurgulamışlardır. Yöneticilere göre öğretmenler söz konusu bu durumu angarya olarak görüyor olabilirler. Bunun yanında yöneticiler, öğretmenlerin değişime karşı direnç göstererek muhalif davranışlar sergileyebileceklerini belirtmişlerdir. Değişimin planlı olup olmadığı yada okul açısından olumlu sonuçlar doğurup doğurmayacağına bakmaksızın, değişimi baştan reddetmek, kişisel 
çıkarın zedelenmesiyle ilişkili olabilir. Nitekim bazı yöneticiler, öğretmenlerin kişisel çıkarları zedelendiği için muhalif bir tutum içinde olabileceklerini belirtmişlerdir.

Bazı yöneticiler, öğretmenlerin, okul idaresinin aldığı kararların alınma biçimine ve içeriğine karşı muhalif davranışlar sergilediklerini belirtmişlerdir. Yöneticiler karar alımlarında, özellikle de öğretmenleri ilgilendiren konularda, öğretmenlere her zaman danışılarak alınmasını, aksi takdirde öğretmenlerin muhalif davranışlar sergileyebileceklerini vurgulamışlardır. Yöneticiler son yıllarda, Milli Eğitim Bakanlığı'nın teknolojik alt yapıyla geliştirdiği projelerin eğitime entegre edilmesinde öğretmenlerin yetersizliğinden kaynaklanan birtakım sorunlar yaşandığını ifade etmişlerdir. Bu sorunlardan en önemlisi, söz konusu öğretmenlerin, değişen ve gelişen sistemde kendilerine verilen görevleri yapmak istememeleridir. Bazı yöneticiler, öğretmenlerin yetersiz olduklarında muhalefet edebileceklerini belirtmiştir. Yöneticiler, okuldaki görev ve sorumluklarını yerine getiren öğretmenlere karşı daha esnek davrandıklarını, bu durumun ise diğer öğretmenlerce kayırma olarak değerlendirildiğini bildirmişlerdir.

Öğretmenlerin, hoşlanmadıkları bir durumla karşılaştıklarında sergiledikleri muhalif davranış biçimlerine ilişkin alt temalar ve frekansları Tablo 2'de verilmiştir.

Tablo 2.

Muhalif Davranış Biçimlerine iliş̧kin Alt Temalar ve Frekansları.

\begin{tabular}{llr}
\hline Ana tema & Alt temalar & $\mathbf{f}$ \\
\hline Muhalif davranış biçimleri & Yatay muhalefet & 9 \\
& Dikey muhalefet & 6 \\
& Haber uçurma & 3 \\
& Yer değiştirmiş muhalefet & 2 \\
& Toplam & 20 \\
\hline
\end{tabular}

Tablo 2 incelendiğinde, öğretmenlerin sergiledikleri muhalif davranış biçimlerinin sırasıyla; yatay muhalefet, dikey muhalefet, haber uçurma ve yer değiştirmiş muhalefet alt temalarında olduğu görülmektedir.

Okul yöneticilerine göre, öğretmenler en fazla, yatay muhalefet stratejisini tercih etmektedir. Bu konuyla ilgili olarak yönetici görüşleri; “...Bazı öğretmenlerimiz verdiğimiz görevlerle ilgili, direkt itiraz etmemekte ancak kaytarma, görevi ağırdan alma, istenilen düzeyde yapmama, küsme, tavır yapma, soğuk davranma yoluna gidiyor (K9).", “...Nöbetin gereksiz olduğunu düşünen öğretmenlerimiz, nöbet görevini istediğimiz şekilde yapmıyor. Öğrenciler arasında eli cebinde dolaşıyor, hiçbir şeye karışmıyor. Aklınca bizi protesto ediyor (K6)." şeklindedir.

Öğretmenler, yatay muhalefet stratejisinden sonra en fazla dikey muhalefet stratejini tercih etmektedir. Bu konuyla ilgili olarak bir yönetici görüşü; “...Okulda yaptığımız toplantılarda öğretmenlerimizle görüş alı̧ verişinde bulunuruz. Ancak öğretmenlerin hoşuna gitmeyen durumlar olunca, itiraz yoluna gitmektedir. Çoğu zaman verdiğimiz kararları değiştirmek için bizi ikna etmeye çalışıyorlar (K13)." şeklindedir.

Haber uçurma stratejisi ile ilgili olarak bir yönetici görüşü; “...Bir öğretmenimiz son derse girmemek için izin istedi. Önemli bir nedeni olmadığı için, izin vermedim. $O$ günden sonra, öğretmen arkadaşımız benim açı̆̆ımı aramaya başladı. Bir seferinde resmi bir toplantıya katılmak için okuldan ayrıldığımda mesai saatleri içerisinde okulu terk ettiğim gerekçesiyle bu durumu tutanak altına alıp sendikalarına rapor ettiler (K8)." şeklindedir.

Öğretmenler, nadiren de olsa yer değiştirmiş muhalefet stratejini tercih etmektedir. Bu konuyla ilgili olarak bir yönetici görüşü; “...Bir öğretmenimiz sene sonunda yanıma gelerek, bir sonraki dönem başlangııında mesleki çalışma döneminde her gün okula biraz gecikeceğini söyledi. Ben de, 'neden olmasın, o dönem gelince bana hatırlat' dedim. Ama o dönem gelince bana hatırlatmadan okula geç 
gelmeye başladı. Biz de insanız unutuyoruz. Kendisini uyardığımızda ise, aramızda geçen konuşmaları hatırlattı bana. Ben de bana hatırlatmadığı için izin vermedim kendisine. Ertesi hafta, bu olayı Mardin'de birçok kişiden duydum. Bizim camiadan kimi görsem bana bu olaydan bahsediyordu (K9)." şeklindedir.

Görüşülen yöneticiler genel olarak öğretmenlerin hoşlanmadıkları bir durum olduğunda direkt olarak kendilerine itiraz etmediklerini belirtmiştir. Öğretmenlerin, kendilerine bir görev verildiğinde itiraz yoluna gitmemelerinin nedeni, ast-üst ilişkisi kapsamında hareket etmek istemeleri olabilir. Bunun yanında yöneticiler, iyi ilişkiler geliştirdikleri öğretmenlerin nadiren de olsa kendilerine direkt itiraz yoluyla muhalefet edebileceklerini de bildirmişlerdir. Yöneticiler, öğretmenlerin çok azının okul içinde karşılaştığı sorunları okul dışına aktardıklarını vurgulamıştır.

\section{Sonuç, Tartışma ve Öneriler}

Bu araştırma, ilkokul ve ortaokullarda görevli yöneticilerin örgütsel muhalefete ilişkin görüşlerini ortaya koymayı amaçlamaktadır. Çalışmada, okullardaki örgütsel muhalefete ilişkin yönetici görüşleri doğrultusunda ulaşılan sonuçlar, ilgili literatür çerçevesinde araştırılmış ve kendi bağlamında tartışılmıştır.

Araştırmada öğretmenlerin; görev ve sorumluluk, değişime direnç, kişisel çıkarın zedelenmesi, kararların alınma biçimi ve içeriği, öğretmenlerin yetersizliği, etik dışı uygulamalar, önyargı, adaletsiz uygulamalar, muhalefet için muhalefet, etkisiz uygulamalar, performans değerlendirme, kaynakların temin edilmesi ve kullanılmasına karşı muhalif davranışlar sergiledikleri sonucuna ulaşılmıştır. Araştırmada yönetici görüşlerine göre, öğretmenlerin en çok kendilerine verilen görev ve sorumluluk, değişime direnç ve kişisel çıkarların zedelenmesi noktalarında muhalif davranışlar sergileme eğilimi içerisinde oldukları saptanmıştır.

Yöneticiler öğretmenlerin bir bölümünün, kendilerine verilen bazı görevleri bir tür "angarya” olarak gördüğünü ve çeşitli gerekçeler öne sürerek yöneticilere muhalefet ettiklerini ifade etmişlerdir. Köksal da (2008), araştırmasında öğretmenlerin verilen bazı görevlere direnç gösterdikleri ya da görevleri angarya olarak gördükleri sonucuna ulaşmıştır.

Araştırmada, öğretmenlerin muhalefet etmesinde rol oynayan etkenlerden birinin de değişim olduğu bulgusuna ulaşılmıştır. Alandaki genel kabul, örgüt üyelerinin örgütsel yenileşme ya da değişime direnç gösterdikleri yönündedir (Korkut, 2009; Zayim, 2005). Yöneticiler öğretmenlerin kişisel çıkarları zedelendiği için kararlara muhalefet ettiklerini belirtmişlerdir. Yönetici ve astlar arasındaki anlaşmazlıkların çözümüne yönelik bir araştırma gerçekleştirmiş olan Baykal ve Kovancı (2008), örgütlerde karşılaşılan çatışma nedenlerinden birinin de yönetici ve çalışanlar arasındaki çıkar ayrılıkları olduğu ifade etmektedir. Bu bulguya dayalı olarak çıkar ayrılıklarının çatışmaya yol açtığı gibi örgütsel muhalefeti de tetiklediği öne sürülebilir.

Öğretmenler, yöneticilerin örgütsel kararlar ve bu kararların alınma biçiminin etkisiyle de muhalif davranışlar sergileyebilmektedir. Özdemir'in (2010) ve Ağalday'ın (2013) çalışmasında elde edilen sonuçlar ile Kassing ve Armstrong (2002)'un “Örgütsel Muhalefeti Tetikleyen Olayların Tipoloji"sinde belirttiği "Örgüt Üyelerine Yönelik Davranışlar" ve "Karar Alımı" kavramları, bu bulguları destekler niteliktedir. Örgüt yöneticilerinin, örgütsel uygulamalarla ilgili karar vermesi, liderlik stilleriyle ilgilidir. Bu araştırmada, öğretmenlerin daha çok, otoriter yönetim anlayışına karşı muhalif davranışlar sergileyebilecekleri sonucuna ulaşılmıştır. Otoriter yönetim anlayışında yönetici, bütün yetkiyi kendi elinde toplamaktadır. Oysaki örgüt üyeleri ihtiyaç ve tercihlerini dikkate alan, karar alımlarında çoklu katılımı esas alan demokratik yönetim anlayışını esas almaktadır. Gerektiğinde alınan kararların sorgulanmasına fırsat tanınmalı, öğretmenlerle ilgili alınan kararlar tüm gerekçeleriyle birlikte gerektiğinde açıklanmalı ve öğretmenler zamanında haberdar edilmelidir. Özetle, okulda bilgi akışını sağlayan etkili bir sistemin, okul yöneticileri tarafından oluşturulması gerekmektedir. 
Bu çalışmada ortaya çıkan bulgulardan biri, öğretmenlerin, etik dışı uygulamaları muhalefet etme nedeni olarak görmeleridir. Öğretmenler yöneticilerin bazı uygulamalarını yanlı buldukları için muhalefet etmektedirler. Bu uygulamalardan biri de yöneticilerinin kimi zaman bazı örgüt üyelerini kayırmalarıdır (Aydın, 2002, s.60; Bozkurt ve Ergun, 1998, s.117). Özdemir (2010)'in ve Ağalday (2013)'ın çalışmasında elde edilen sonuçlar, Kassing ve Armstrong (2002)'un “Örgütsel Muhalefeti Tetikleyen Olayların Tipoloji"sinde belirttiği "Etik" kavramı, Redding (1985) ve Graham (1986)'ın bulguları, bu bulguyu destekler niteliktedir. Yöneticinin davranışları, örgüt üyeleri tarafından etik açıdan doğru bir biçimde algılandığı zaman anlamlı olur (Arslantaş ve Dursun, 2008, s.115). Yöneticinin etik dışı söylem ve davranış geliştirmesi, örgüt içi iletişim iklimine zarar vereceği için, verimliliği düşürecektir.

Bu çalışmada ayrıca, yöneticilerin örgütsel adalet ile ilgili algılarının, öğretmenlerin muhalefet etmesine neden olduğu anlaşılmaktadır. Yöneticilerin örgüt üyelerine yönelik davranışlarının adaletsiz ve örgüt üyelerinin haklarını ihlal edici yönde olması durumunda, öğretmenlerin muhalefet ettikleri görülmektedir. Araştırmada, yöneticilere göre, öğretmenler okullarda hoşlanmadıkları bir durumla karşılaştıklarında; yatay muhalefet, dikey muhalefet, haber uçurma ve yer değiştirmiş muhalefet stratejilerini tercih ettikleri sonucuna ulaşılmıştır.

Yöneticilere göre öğretmenlerin sergiledikleri muhalif davranışlar incelendiğinde, daha çok yatay muhalefet stratejisini tercih ettikleri anlaşılmaktadır. Yöneticilerin görüşleri incelendiğinde, öğretmenlerin küsme davranışını sergileyebileceği belirtilmiştir. Ortaya çıkan bu bulgu Hirschman'ın 'ayrılma-dile getirme-sadakat' kuramını desteklemektedir. Çalışmasında Hirschman (1970), örgüt içerisinde mutlu olmayan örgüt üyelerinin bir bölümünün örgütten ayrılma (exit) davranışı sergileyeceklerini öne sürmektedir. Yine bu bulgu Gorden ve Infante (1987) tarafından ortaya atılmış olan 'bağımsız düşünme kuramı'nı desteklemektedir. Söz konusu kuram, örgüt üyelerinin, muhalif görüşler de dâhil olmak üzere sahip oldukları her türlü görüşü örgüt içerisinde özgürce ifade etmeleri durumunda işe daha fazla bağlı olacaklarını öne sürmektedir. Bu önermeye bağlı olarak muhalif görüşlerini açık bir biçimde ifade edemeyen, diğer bir ifade ile yöneticilere küsen örgüt üyelerinin, örgüte olan bağlııklarının azalacağı da düşünülebilir. Dolayısıyla, örgüte bağlılık düzeyi azalan örgüt üyelerinin örgütten ayrılma eğilimine girmeleri beklendik bir durumdur. Bir örgütte çalışanlar, kendilerini ne kadar çok örgütün bir parçası, örgütü de kendilerinin bir parçası gibi görürlerse, bulundukları örgütün üyeliğine ne kadar içten bağlanırlarsa, örgütte o kadar çok kalmak isterler. Örgütte ortak çalışmaya katkıda bulunmak için içten fazla bir çaba gösterirler (Aydın, 2007, s.23). Bu çalışmada öne çıkan temel bulgulardan biri de, muhalif görüşlere sahip olan, ancak bu görüşlerini açıkça dile getiremeyen öğretmenlerin küsme davranışını sergileyebileceği yönündedir.

Öğretmenler aynı zamanda yatay muhalefet stratejisi kapsamında iş yavaşlatmaya da gidebildiği tespit edilmiştir. Farrell ve Rusbult (1992) bu tür davranışları 'ihmal' (neglect) davranışı olarak nitelemekte ve bu tür davranışlara örnek olarak örgüt üyelerinin çalışma azminin yok olmasını, işe geç gelmeyi alışkanlık haline getirmelerini ve işten kaçmalarını göstermektedir. Bazı durumlarda, örgüt üyeleri, örgütteki kimi uygulama ya da politikaya karşı, çıkarlarının zedeleneceği endişesiyle, muhalif görüşlerini açıkça ifade etmezler. Bu durum, örgüt üyelerinin ya sessiz kalmasına ya da örgüt üyelerinin muhalif görüşlerini örgütteki diğer arkadaşlarına anlatmasına neden olmaktadır (Kassing ve Avtgis, 1999, s.103).

Öğretmenler, yatay muhalefet stratejisinden sonra en çok "dikey muhalefet" stratejisini tercih etmektedirler. Açıkça belirtilmiş muhalefet, örgüt üyelerinin görüş ayrılı̆̆ına düştükleri uygulamaları, üstlerine doğrudan yada dolaylı yollarla ifade etmeleridir (Kassing, 2002). Graham (1986) da çalışmasında, örgüt üyelerinin bir bölümünün ilkesel nedenlere dayalı olarak yöneticilere doğrudan muhalefet ettiklerini ifade etmektedir. Benzer şekilde Kassing (1998) bir kısım örgüt üyesinin muhalif görüşlerini doğrudan yöneticilere ifade ettiklerini belirtmiş ve bu davranış biçimine 'dile getirilmiş muhalefet' adını vermiştir. Söz konusu stratejinin, okul yöneticileriyle öğretmenler arasında ilişkilerin iyi düzeyde olması durumunda tercih edildiği ve okul içinde demokratik yapının gelişimine katkı sağladığı bilinmektedir (Kassing, 1998). Bu nedenle öğretmenlerin "dikey muhalefet" stratejisini daha çok tercih 
edebilecekleri ortamların, yöneticilerce sağlanması, muhalefetin etkin yönetimine katkı sağlayacağı düşünülmektedir.

Öğretmenler okulda hoşlanmadıkları bir durumla karşılaştıklarında, bu durumu yetkili kurum ve kuruluşlara rapor ettiği de tespit edilmiştir. Haber uçurma, bir organizasyon içerisinde yasadışı ve etik değerlere uygun olmayan davranış ve eylemlerin organizasyon içi ve/veya organizasyon dışı başka kişilere veya kurumlara zarar vermemesi için enformasyon sahibi kişiler (çalışanlar veya paydaşlar) tarafından sorunları çözme güç ve yetkisine sahip iç ve dış otoritelere bildirilmesidir (Aktan, 2006, s.1). Öyle anlaşılmaktadır ki, kimi öğretmenler yöneticilerin çeşitli tutum ve davranışını sendikalara iletme eğilimindedir. Yukarıdaki alıntıda da görüldüğü gibi bu öğretmenler özellikle bağlı oldukları sendikalar aracılığı ile yöneticilere muhalefet etmektedir. Ancak birçok öğretmen de zarar göreceği endişesiyle okul içinde yaşadığı olumsuzlukları dışarıya rapor etmeyebilir. Bunun için öğretmenlerin muhalif görüşlerinin örgüt dışı etkin muhataplara iletebilmesi için okulda gerekli önlemlerin alınması ve yasal düzenlemelerin yapılması gerekmektedir.

Yöneticilere göre öğretmenler çok az da olsa "yer değiştirmiş muhalefet" stratejisini tercih ettikleri görülmektedir. Yer değiştirmiş muhalefet ise, muhalif görüşlerin örgüt dışında ve örgüt üzerinde etkili olmayan kişilere anlatılmasıdır (Kassing, 1998). Örgüt üyeleri, muhalif görüşlerini örgüt dışındakilere dile getirerek, kendilerine yönelik sergilenecek misilleme davranışlarını azaltma amacı taşımaktadırlar. Örgüt üyeleri, örgütten ayrılmayı fiziksel olarak düşünmemekle birlikte, muhalif görüşlerini örgütsel sınırların dışında kalanlarla paylaşarak psikolojik olarak örgütten ayrılmayı deneyebilirler (Kassing, 1997, s.326). Örgüt içinde herhangi bir yönetimsel pozisyonda bulunmayıp, örgüt dışındaki güç odaklarıyla iyi ilişkiler içinde olan örgüt üyeleri, daha çok yatay muhalefet stratejisini tercih ederler (Kassing, 1998, s.193; Kassing ve Armstrong, 2009, s.226; Kassing ve Avtgis, 2009, s.120). Bunun yanında, iş deneyimi daha az olan genç yaştaki örgüt üyeleri, yer değiştirmiş muhalefet stratejisini tercih ederler (Kassing ve DiCioccio, 2009, s.114).

Bulgulara dayalı olarak aşă̆ıdaki öneriler geliştirilmiştir:

- Okul yöneticilerine etkili iletişim semineri verilmesi,

- Okul yöneticileri okul işleri dışında öğretmenlerle belirli zaman aralıklarıyla birebir görüşme saatleri ayarlanması,

- Okuldaki örgütsel iklimin gelişimi için, okul yöneticileri ve öğretmenlere yönelik uygulamalı iletişim seminerleri verilmesi,

- Öğretmenlerin muhalif görüşlerinin örgüt dışı etkin muhataplara iletebilmesi için okulda gerekli önlemlerin alınması ve yasal düzenlemelerin yapılması,

- Öğretmenlere "dikey muhalefet" stratejisini daha çok tercih edebilecekleri ortamların, yöneticilerce sağlanması yararlı olacaktır.

\section{Kaynakça}

Ağalday, B. (2013). Illköğretim okullarında görevli öğretmenlerin örgütsel muhalefete ilişkin görüşleri. Unpublished master thesis, Dicle Üniversitesi Eğitim Bilimleri Enstitüsü, Diyarbakır.

Aktan, C.C. (2006). Organizasyonlarda yanlış uygulamalara karşı bir sivil erdem, ahlaki tepki ve vicdani red davranışı: Whistleblowing. Mercek Dergisi, 1(13), 1-13.

Ardoğan, R. (2004). Teorik temeller ve tarihsel gerilimler arasında islam kültüründe siyasal muhalefet. Cumhuriyet Üniversitesi Ilahiyat Fakültesi Dergisi, 8(2), 171-189.

Arslantaş, C.C. \& Dursun, M. (2008). Etik liderlik davranışının yöneticiye duyulan güven ve psikolojik güçlendirme üzerinde etkisinde etkileşim adaletinin dolaylı rolü. Anadolu Üniversitesi Sosyal Bilimler Dergisi, 8(1), 111-128. 
Bünyamin AĞALDAY, Habib ÖZGAN ve Mustafa Cüneyt ARSLAN - Pegem Eğitim ve Öğretim Dergisi, 4(3), 2014, 35-50

Aydın, i.(2002). Yönetsel mesleki ve örgütsel etik. Ankara: Pegem Yayıncılık. Aydın, M. (2007). Çağdaş eğitim denetimi. Ankara: Hatipoğlu Yayınevi.

Aydın, i. (2010). Eğitim yönetimi. Ankara: Hatiboğlu Yayınevi. Baykal, K. \& Kovancı, A. (2008). Yönetici ve astlar arasındaki anlaşmazlıkların çözümüne yönelik bir araştırma. Havacılık ve Uzay Teknolojileri Dergisi, 3, 21-38.

Bilgin, N. (2006). Sosyal bilimlerde içerik analizi: teknikler ve örnek çalışmalar. Ankara: Siyasal Kitabevi.

Bozkurt, Ö. \& Ergun, T. (1998). Kamu yönetimi sözlüğü. Ankara: TODAiE Yayınları.

Farrell, D. \& Rusbult, C. E. (1992). Exploring the exit, voice, loyalty, and neglect typology: the influence of job satisfaction, quality of alternatives, and investment size. Employee Responsibilities and Rights Journal, 5, 201-218.

Gorden, W.I. \&Infante, D.A. (1987). Employee rights: content, argumentativeness, verbal aggressiveness and career satisfaction. Communicating Employee Responsibilities and Rights: A Modern Management Mandate, 149-163.

Graham, J.W. (1986). Principled organizational dissent: a theoretical essay. Research in Orgazizational Behavior, 8, 1-52.

Hegstrom, T. G. (1991). Mimetic and dissent conditions in organizational rhetoric. Journal of Applied Communication Research, 18, 141-152.

Hirschman, A. O. (1970). Exit, voice, loyalty. Cambridge: Harvard University Press.

Kassing, J. W. (1997). Articulating, antagonizing, and displacing: a model of employee dissent. Communication Studies, 48(4), 311-332.

Kassing,J.W.(1998). Development and validation of the organizational dissent scale. Management Communication Quarterly, 12(2), 183-229.

Kassing, J.W. (2001). From the looks of things: assessing perceptions of organizational dissenters. Management Communication Quarterly, 14(3), 442-470.

Kassing, J.W. (2002). Speakingup: identifying employees' upward dissent strategies. Management Communication Quarterly, 16(2), 187-209.

Kassing, J.W. (2008). Consider this: a comparison of factors contributing to employees' expression of dissent. Management Communication Quarterly, 56(3), 342-355.

Kassing, J.W. \& Armstrong, T. A. (2002). Someone's going to hear about this: examining the association between dissent-triggering events and employee's dissent expressions. Management Communication Quarterly, 16(39), 39-65.

Kassing, J.W. \& Armstrong, T. A. (2009). Examining the association of job tenure, employment history and organizational status with employee dissent. Communication Research Reports, 18, 264-273.

Kassing, J.W. \& Avtgis, T.A. (1999). Examining the relationship between organizational dissent and aggressive communication. Management Communication Quarterly, 13(100), 76-91.

Kassing, J. W. \& Avtgis, T.A. (2009). Dissension in the organization as a function of control expectancies. Communication Research Reports, 18, 118-127.

Kassing, J. W. \& DiCioccio, R. L. (2009). Testing a workplace experience explanation of displaced dissent. Communication Reports, 17, 111-120.

Korkut, M. (2009). Ilköğretim Okullarında Görev Yapan Öğretmenlerin Örgütsel Değişmeye ilişkin Görüşleri-Çanakkale ili Örneği. Unpublished master thesis, Çanakkale On Sekiz Mart Üniversitesi Sosyal Bilimler Enstitüsü, Çanakkale.

Köksal, N. (2008). Öğretmenlik mesleği genel yeterliklerinin öğretmen, müdür ve bakanlık yetkilileri tarafından değerlendirilmesi. Pamukkale Üniversitesi Eğitim Fakültesi Dergisi, 23, 36-46. 
Bünyamin AĞALDAY, Habib ÖZGAN ve Mustafa Cüneyt ARSLAN - Pegem Eğitim ve Öğretim Dergisi, 4(3), 2014, 35-50

Krone, K. J. (1992). A comparison of organizational, structural, and relationship effects subordinates' upward influence choices. Communication Quarterly, 40, 1-15.

Özdemir, M. (2010). Ankara ili kamu genel liselerinde görev yapan yönetici ve öğretmenlerin örgütsel muhalefete ilişkin görüşleri. Unpublished doctoral dissertation, Ankara Üniversitesi Eğitim Bilimleri Enstitüsü, Ankara.

Redding, W. C. (1985). Rocking boats, blowing whistles, and teaching speech communication. Communication Education, 34, 245-258.

Stanley, J. D. (1981). Dissent in organizations. The Academy of Management Review, 6, 13-19.

TDK, (1998). Türkçe sözlük. Ankara: TDK Yayınları.

Yıldırım, A. \& Şimşek, H. (2011). Sosyal bilimlerde nitel araştırma yöntemleri. Ankara: Seçkin Yayıncılık.

Zayim, N. (2005). Tıp bilişiminde teknolojik değişim yönetimi; insan ve organizasyona ilişkin konular. 2. Ulusal Tıp Bilişimi Kongresi, Tıp Bilişimi Derneği, Antalya. 